\title{
Dynamic Learning for the Arabic language
}

\author{
Muh Barid Nizarudin Wajdi \\ Program Doktor Pendidikan Agama Islam Universitas Muhammadiyah Malang \\ Baridnizar84@gmail.com
}

\begin{abstract}
The teaching of Arabic is very interesting to be studied in comprehensive. Not only because of its function and essence for the life of Islamic communication, but because of its nature that is in the midst of ongoing education traditions are in need of various innovations, as a logical consequence the development of science and technology. The development of science and technology that is so rapidly for human life, it is necessary to work on language teaching technicians. In addition to the above, more interesting, in the spotlight that has a criticism from experts and society to the ability of students or students, especially students of IAIN or STAIN against the Arabic language. From the existing phenomenon, many among Islamic education institutions in Indonesia, more leaving the impression of the importance of teaching grammar mastery alone, as seen in memorizing the rules of language. Consequently we will not be surprised that while there is one who is good at mastering the Arabic grammar, but weak in terms of the functioning of the Arabic language itself, as a language of communication. Therefore, in this paper we are trying to raise the theme of "A general perspective on learning Arabic
\end{abstract}

Keyword : Dynamic Learning, Arabic language, Non Arab

\section{INTRODUCTION}

Learning is a teaching activity that is done maximally by a teacher so that the students he teaches certain materials do the learning activities well. In other words, learning is an effort made by teachers to create learning activities that are conducive to achieving goals. Thus, learning foreign language is a teaching activity that is performed maximally by a teacher so that the students he teaches a certain foreign language has a good learning activity, so it is conducive to achieving the objectives of learning Foreign languages (Hermawan, 2011).

In language learning there are three terms that need to be understood understanding and the concept precisely, namely approaches, methods and techniques. Edward M Anthony in his article "Approach, Method and Technique" The three terms are as follows (Rosyidi, 2011):

1. Approach, which in Arabic called aoufous is a set of assumptions concerning the nature of the language and the nature of learning language teaching. An axiomatic or philosophical approach that is oriented towards establishment, philosophy, and belief is something that is believed but not necessarily demonstrable. 
2. The method, which in Arabic called Thariqah is a thorough plan that pertains to the presentation of the material regularly or systematically based on the prescribed approach. If the approach is axiomatic, then the method is procedural. So in one approach there can be several methods.

3. While the technique, which is in Arabic called uslub or popular in our language with strategy, namely the specific activities that are implemented in the classroom, in accordance with the approaches and methods that have been chosen. The technique is operational, because it depends on the imagination and the creativity of a teacher in your materials and overcoming and solving problems in the classroom.

From the above exposure can be understood, that these three terms have a hierarchical relationship. From one approach can bring one or several methods, and from one method can implement one or several strategies. Instead the strategy should be consistent with the method and therefore should not contradict the approach.

According to Oemar Hamalik the understanding of learning is an organized communication covering human elements, materials, facilities, equipment and procedures that influence each other to achieve the purpose of learning, in this case man involved In the teaching system consists of students, teachers and other energy(Shvoong, 2017). In the study of interactions between teachers and students, one side of the teacher performs an activity that leads the child toward the destination, more than that a child or student can undertake a series of activities that the teacher has planned to Directed toward the goal to be achieved. In the meantime, Arabic is one of the world's languages that have undergone social development of society and Science. Arabic language in the study of history including the Semitic language is a family of languages that are used by nations living around the Tigris and Furat rivers, the plains of Syria and the Arabian Peninsula (Middle East) (Arsyad, 2003). Thus the learning of Arabic language can be defined as an attempt to teach the students to learn Arabic with the teachers as facilitators by organizing various elements to achieve the objectives.

\section{DISCUSSION}

\section{The purpose and importance of Arabic language learning}

Language learning is needed so that one can communicate properly and properly with its neighbor and its environment, both orally and in writing. The purpose of language learning is to develop Arabic language and proficiency, such as Muthala'ah, Muhadatsah, Insya ', Nahwu and Sharaf, thus gaining language proficiency which includes four aspects of proficiency, namely (Bustami, 1987):

1. Listening Skills

Listening skills as a receptive language proficiency, receiving information from other people (speakers). 
2. Reading skills

Reading skills are language skills that are receptive, receiving information from other people (authors) in the form of writing. Reading is a change of writing into meaning.

3. Writing Skills

Writing skills are language skills that produce or give information to others (readers) in the form of writing. Writing is a change in form of thought or feeling into a text.

4. Speaking Skills

While speaking skills are skills that are productive, produce or convey information to others (storage) in the form of language sounds (utterance is the process of changing the form of language sounds into speech form

The Department of Religion explains that the general purpose of Arabic language learning is (Taufiq, 2013):

1. To be able to understand the Quran and Hadith as a source of Islamic teachings.

2. To be able to understand the books of religion and Islamic culture written in Arabic.

3. To be able to speak and compose in Arabic

4. To be used as another skill helper (supplementary).

5. To foster an Arabic language expert, that is really professional.

In addition, the purpose of teaching Arabic is to introduce various forms of language science to learners who can help with language proficiency, using different forms and various languages to communicate, both in Both oral and written form, to achieve that purpose of teachers or linguists, curriculum makers or learning programs should consider materials or materials that are appropriate to the level of learners and seek methods or techniques Teaching language Science and Arabic language proficiency, and training learners in daily life, good reading, writing and speaking skills.

Basic skills that must be possessed in understanding the Arabic language in mastering the language science and proficiency of Arabic and its principles, memorizing or mastering the Vocabulary (mufradat) and its meaning. The Arabic rules are studied in NAHWU and Sharaf subjects. Whereas the Mufradat can be mastered through Muthala'ah and Muhadatsah courses, because both courses rely heavily on vocabulary-mastery.

In mastering the rules of Arabic need to the mastery of NAHWU and Sharaf. NAHWU is used to study sentence structure and final line changes. While Sharaf is used to learn the basic word and its changes. Furthermore, to gain listening skills and reading need to study science Muthala'ah. To acquire the skills of writing or 
making the need to study the sciences ' and to acquire the skills of speaking need to study the science of Muhadatsah.

While the importance of Arabic language learning is Arabic is one of the major languages that are widely used in various parts of the world (Zainudin, 2005). Since the Middle Ages the Arabic language became a universal language which eventually made it one of the world's most popular languages such as Greek, Latin, English, French, Spanish, and Russian. And currently the Arabic language is one of the languages used to write the United Nations (UN) documents.

On the other hand, Arabic is also the language of the Qur'an, this is what makes Arabic a language that is very related to Islam, because it is the language of religion for all Muslims in the world, both for those who use the Arabic language in Their daily lives or not. This is because the Muslims read the Qur'an in the original language, namely Arabic. No translation of the Qur'an is made in all languages that allow them to replace the original language. So also the prayer of five time and prayers, and the Azan all use the Arabic language Fusha.

From the fact and reality above, we can know and understand the importance of Arabic, especially for Muslims who reside in Arab and other people. However, the problem is in the study for foreigners (non-Arabs), as well as the Arabic language learning in our country where the majority of the population is Muslims. We also know that the Arabic language is one of the foreign languages taught in some schools in Indonesia, whether it is a school in the city and in villages. And mostly, Arabic is taught in madrasas and boarding schools scattered throughout Indonesia, ranging from elementary school to college.

Basically, learning foreign language is not easy, but there are often difficulties faced by teachers and students. Some of those difficulties were that of Muhammad Athiyah Al-abrasive, that in the study of foreign languages, the majority of students still memorized sentences (IELTS) but were unable to understand its meaning (Zainudin, 2005). It should be that teachers should not force and burden pupils with memorization of unknown sentences, because they are not a good way to learn a foreign language. Based on that, we certainly need a strategy that is a surefire in overcoming the difficulties in foreign language learning, especially Arabic language. This is intended for learning to achieve a set of goals and objectives.

\section{Levels in Arabic language learning}

It should be noted in the learning of Arabic with the aim to eliminate the impression that the Arabic language is difficult and dizzying then the teacher must understand the level of pupils being taught, in order to provide material according to the student level at the time It.

Giving the appropriate material will accelerate the students ' understanding, do not arrive at the time of the students at Beginner level (Mubtadi'in) in learning the 
Arabic language, teachers give material that is too difficult as fabricated, telling the story in Arabic of course it Will make new students learn Arabic will find it very difficult, so that the understanding of students that the Arabic language is hard, as well as the reverse provision of material that is too light to the students who are already at the Advanced level ( Mutaqodimin) will make students feel bored quickly because the material he has mastered, the initial introduction to the student level will be very helpful to a teacher in giving a suitable material, it is in accordance with Joseph said that Arabic language learning needs to be prepared with good material tailored to the development level of the students

To avoid the impression that learning the Arabic language is difficult then all we have to implement is(Wajdi 2015, 2016):

1. Teach Arabic conversations with words that are simple and easy to understand by learners

2. Using props or tools, it is important that learning is interesting, passionate, and easy to understand

3. Activate the entire student's senses, the tongue is trained with the conversation, the eyes are trained by reading, and hand trained by writing and composing

In Arabic learning we have learned that the level of Arabic language learning consists of:

1. Mubtadi'in (beginner) is the earliest level in the learning of Arabic language, and usually the most suitable material for this level is: memorize mufrodat, simple conversation, and write directed (Insya ' Muwajahah) Usually used at lower levels because it includes fabricated activities that start from arranging letters, then words and sentences

2. Mutawasitin (intermediate) When students at this level means he has gained some material about the Arabic language, and the task of a teacher at the time is to provide reinforcement to the materials that have been obtained by the students, so that it can Proficient in the material

3. Mutaqodimin (Proficient) at this level students have begun to proficient in Arabic language materials and materials that are suitable for students who are already at this level is making free (Insya hur) is usually used at a high level because The creativity of a writer is very reliable.

There are other opinions on the levels of learning Arabic, which is the beginner level translated with Al-Marhalat al-Ûla, in English is referred to as Elementary Level. While the intermediate level in Arabic is translated with al-Marhalat alMutawassithah, the English language is called Intermediate Level.

According to Dr. Ali Al-Hadîdi, the term beginner or intermediate in the world of language learning, including Arabic, can be measured from two aspects: first, aspect of the number of students Mufradât mastery (Bustami, 1987). For the beginner level, the Mufradât to be mastered is 0 to 1,000 words, as well as for the 
intermediate level, (1,000 S/d. 2,000 words). Second, in terms of number of hours lessons. For beginner level, the number of hours of the lesson to be passed reaches 0 to 250 hours; 200 hours spent formally at school and 50 hours for tasks etc. The number and allocation of hours above, also applies to "intermediate level" which is 250 lesson hours: Consisting of: 200 hours in class (in teacher guidance), and more outside of class, such as daily tasks (at least two hours a day) both independently and Group.

Noting the above limitation, it is known that it is said that beginner level if it has mastered a number of 1,000 words. As for the intermediate level, you have to master 2,000 mufaradat. On the other hand, the number of hours that must be skipped reaches 250 hours.

Based on the above limitation, beginner or intermediate term should not be formally understood, such as to match beginner to SD or MI, as well as JLTP or MTs and SLTA or Madrasah Aliyah by medium, as each level is measured by The mastery of a number of vocabulary and the hours of lessons that have been passed. Then it can be someone who is 30 years old but just beginning to learn the language is called as a beginner, or vice versa students who are only 10 years old, but have mastered vocabulary and the middle level lesson hours called as intermediate level.

\section{CONCLUSION}

Arabic language learning can be defined as an effort to teach students to learn Arabic with teachers as facilitators by organizing various elements to achieve the objectives.

The purpose of language learning is to develop Arabic language and proficiency, such as Muthala'ah, Muhadatsah, Insya ', Nahwu and Sharaf, thus gaining language proficiency that includes four aspects of proficiency. While the importance of learning Arabic is Arabic is the language of the Qur'an, this is what makes Arabic to be a language that is very related to Islam, because it is the language of religion for all Muslims in the world, good for them who use Arabic in their daily lives or not.

Some of the levels in Arabic language learning are first, Mubtadi ' (beginner), second, Mutawassith (intermediate), third, Mutaqaddim (proficient).

\section{REFERENCES}

Hermawan, Acep. 2011. Metodologi Pembelajaran Bahasa Arab. Bandung: PT Remaja Rosdakarya.

Abd Wahab Rosyidi \& Mamlu'atul Ni'mah. 2011. Memahami Konsep Dasar Pembelajaran Bahasa Arab. Malang: UIN-Maliki Press.

Arsyad, Azhar. 2003. Bahasa Arab dan Metode Pengajarannya. Surabaya: Pustaka Pelajar. 
A Gani, Bustami. 1987. Al Arabiyah Bin-Namadzij. Jakarta: PT Bulan Bintang.

Wajdi, Muh Barid Nizaruddin. 2015. “Arabic Learning Skill.” AT-Tahdzib: Jurnal Studi Islam dan Muamalah 3(2): 32-47.

———. 2016. "Arabic Learning Skill." AT-Tahdzib: Jurnal Studi Islam dan Muamalah 3(2): 32-47.

Zainudin, Radliah. 2005. Pembelajaran Bahasa Arab. Jakarta: Pustaka Rihlah Group.

\section{Internet:}

Shvoong. 2012. Pengertian Pembelajaran Bahasa Arab, (online), http ://id. Shvoong.com, diakses pada tanggal 10 Maret 2017.

Najieb Taufiq. 2013. Tujuan Pembelajaran Bahasa Arab, (online), file:///G:/Referensi/tujuan-pembelajaran-bahasa-arab.html, diakses pada tanggal 10 Maret 2017. 